\title{
Soil Microbial Biomass Across a Gradient of Preserved Native Cerrado
}

\author{
Nilza Silva Carvalho ${ }^{1}$, Sandra Mara Barbosa Rocha ${ }^{1}$, Vilma Maria dos Santos ${ }^{1}$, \\ Fabio Fernando de Araujo $^{2}$, Ademir Sérgio de Araújo ${ }^{1}$ \\ ${ }^{1}$ Universidade Federal do Piauí - UFPI, Teresina/PE, Brasil \\ ${ }^{2}$ Universidade do Oeste Paulista - Unoeste, Presidente Prudente/SP, Brasil
}

\begin{abstract}
The different physiognomies and soil conditions across the Cerrado gradient may influence soil microbial biomass. The present study evaluated the soil microbial biomass and enzyme activity across a preserved Cerrado gradient and correlated these with environmental conditions. The site, sampling period and their interaction influenced soil microbial biomass and activity. Soil conditions, i.e., chemical and microclimatic properties, varied across the Cerrado gradient and influenced soil microbial biomass and activity. The highest and lowest values for microbial biomass and enzyme activity were found in Cerradao and Campo graminoide, respectively, during both seasons. Multivariate analysis showed that the sites were clearly separated into different groups, indicating that distinct physiognomies and environmental conditions influenced soil microbial biomass and enzyme activities.
\end{abstract}

Keywords: soil properties, tropical savanna, seasonal variation. 


\section{INTRODUCTION}

The Brazilian Cerrado is recognized as one of the most important tropical biomes, with significant plant and animal diversity (Amaral et al., 2006). However, this biome is one of the least protected: an estimated $6.5 \%$ of the Cerrado is preserved within the Conservation Units (CU) in Brazil (Ribeiro et al., 2016). In northeastern Brazil, Sete Cidades National Park is one important CU, covering $6.221 \mathrm{ha}$, and presents a vegetation gradient from 'Campo graminoide' (grassland formation) to 'Cerrado stricto sensu' (shrubby and arboreal formation) and 'Cerradao' (arboreal formation) (Coutinho, 1978). These different physiognomies across the gradient within Sete Cidades National Park have influenced soil chemical properties and microclimatic conditions (Lucena et al., 2014) and therefore may influence the soil microbial biomass.

Soil microbial biomass (SMB) is the living fraction of soil organic matter (SOM) and participates in several important biological processes, such as organic matter synthesis and decomposition, and nutrient mineralization (Marinari et al., 2006). These biological processes are mediated by soil enzymes that act on the biogeochemical cycles and contribute to the nutrient supply for plants and microorganisms (Burns et al., 2013). Therefore, the evaluation of SMB and its biochemical processes is important to understand the influence of different Cerrado vegetation and environmental conditions on soil microbial properties.

Previous studies in the Brazilian Cerrado have shown that physiognomies with arboreal formation, such as Cerradao, present higher microbial biomass and activity (Nardoto \& Bustamante, 2003; Mendes et al., 2012). However, the studies reported by Nardoto \& Bustamante (2003) and Mendes et al. (2012) evaluated unprotected Cerrado vegetation from the Central Plateau. Thus, the behavior of the soil microbial biomass in a vegetation gradient in a protected Brazilian Cerrado, such as Sete Cidades National Park, remains unclear. Additionally, Sete Cidades National Park presents different types of vegetation and soil conditions from the ones observed in other areas under the Brazilian Cerrado. Therefore, we hypothesized that the different physiognomies and soil conditions across the Cerrado gradient within Sete Cidades National Park would significantly influence soil microbial biomass and biochemical processes. This study aimed to evaluate the soil microbial biomass and enzyme activity across a gradient of different Cerrado physiognomies within Sete Cidades National Park and correlate the results with the environmental conditions.

\section{MATERIAL AND METHODS}

\subsection{Study area}

The study was conducted within Sete Cidades National Park (PNSC) $\left(04^{\circ} 02^{\prime}-08^{\prime} S\right.$ and $\left.41^{\circ} 40^{\prime}-45^{\prime} \mathrm{W}\right)$, located in the northeastern state of Piauí. The park covers an area of 6,221 ha. The climate is sub-humid with two distinct seasons (wet and dry) during the year, with higher annual average temperatures at $25^{\circ} \mathrm{C}$. The area has an annual average rainfall of $1,558 \mathrm{~mm}$, concentrated during February, March and April. Soil is classified as a Typical Quartzipisamment with $926 \mathrm{~g} \mathrm{~kg}^{-1}$ of sand, $39 \mathrm{~g} \mathrm{~kg}^{-1}$ of silt, and $30 \mathrm{~g} \mathrm{~kg}^{-1}$ of clay.

We evaluated preserved sites ( $1.000 \mathrm{~m}^{2}$ each) under Cerrado regime belonging to the long-term ecological program (PELD-CNPq) of the Brazilian government, over a gradient of different Cerrado formations ranging from Campo graminoide (GRA) to Cerrado strictu sensu (CSS) and Cerradao (CD) (Table 1). GRA is mainly covered by a continuous grass stratum that does not exist in $\mathrm{CD}$, whereas $\mathrm{CD}$ is covered by a woody stratum with varying shrub and tree density that is absent in GRA. The intermediary CSS is covered by grass, shrubs, low trees and woody stratum.

Table 1. Vegetation diversity indices in the Cerrado areas.

\begin{tabular}{|c|c|c|c|}
\hline & CG & CSS & CD \\
\hline Plant richness ${ }^{*}$ & 4.7 & 11 & 17 \\
\hline Plant diversity ${ }^{* *}$ & 0.2 & 0.85 & 1.10 \\
\hline Plant density & 4.7 & 27.1 & 35.0 \\
\hline Vegetation $^{* * * *}$ & a & b & c \\
\hline \multicolumn{4}{|c|}{$\begin{array}{l}\text { Campo graminoide (CG); Cerrado strictu sensu } \\
\text { (CSS); Cerradao (CD); }{ }^{*} \text { species } / 100 \mathrm{~m}^{2} ;{ }^{*} \mathrm{H} / 100 \mathrm{~m}^{2} ; \\
{ }^{* * *} \text { individual/100 }{ }^{2} ;{ }^{* * * *} \text { plant species present; }{ }^{\mathrm{a}} \text { Andropogon } \\
\text { fastigiatus; Aristida longifolia; Eragrostis maypurensis } \\
\text { bAndropogon fastigiatus; Aristida longifolia; Terminalia fagifolia } \\
\text { Magonia pubescens; Hymenaea courbaril; Plathymenia reticulata } \\
\text { Qualea grandiflora; Combretum mellifluum; Lippia origanoides } \\
\text { Anacardium occidentale; Simarouba versicolor; Vatairea } \\
\text { macrocarpa; 'Aspidosperma discolor; Parkia platycephala } \\
\text { Terminalia fagifolia; Piptadenia moniliformis; Plathymenia } \\
\text { reticulata; Qualea parviflora; Anacardium occidentale; Copaifera } \\
\text { coriacea; Thiloa glaucocarpa; Casearia grandiflora. }\end{array}$} \\
\hline
\end{tabular}




\subsection{Soil sampling and chemical analysis}

Each site was divided into three transects (replications) where soil samples $(500 \mathrm{~g})$ were collected at a depth of 0-20 cm (three points per transect) in May (rainy season) and October (dry season) 2014. All soil samples were immediately stored in sealed plastic bags and transported in an ice box to the laboratory. A portion of the soil samples $(300 \mathrm{~g})$ was stored in bags and kept at $4{ }^{\circ} \mathrm{C}$ for microbial analysis, and another portion (200g) was air-dried, sieved through a 2-mm screen and homogenized for chemical analyses.

Soil chemical properties were determined and measured using standard laboratory procedures. Soil $\mathrm{pH}$ was determined in a 1:2.5 soil/water extract. Available $\mathrm{P}$ and exchangeable $\mathrm{Ca}, \mathrm{Mg}$ and $\mathrm{K}$ were estimated according to EMBRAPA (1999). Total organic C (TOC) was determined by the wet combustion method using a mixture of potassium dichromate and sulfuric acid under heating (Yeomans \& Bremner, 1998), and total N (TN) was determined by Kjeldahl digestion as described by Bremner (1996). During each soil sampling, the soil temperature was measured for 5 minutes at $10 \mathrm{~cm}$ depth using a probe thermometer.

\subsection{Soil microbial biomass and enzyme activity}

Soil microbial biomass C (MBC) was determined according to Vance et al. (1987) through the extraction of $\mathrm{C}$ from fumigated and unfumigated soils by $\mathrm{K}_{2} \mathrm{SO}_{4}$. An extraction efficiency coefficient of 0.38 was used to convert the difference in $\mathrm{C}$ between fumigated and unfumigated soil in MBC. Basal respiration, dehydrogenase $(\mathrm{DEH})$, and fluorescein diacetate hydrolysis (FDA) were analyzed as measures indicative of general soil microbial activity. Soil basal respiration was determined according to Alef (1995) over seven days. FDA was determined according to the method of Schnürer \& Rosswall (1982). DHA was determined using the method described in Casida et al. (1964). The $\beta$-glucosidase activity was measured as indicated by Eivazi \& Tabatabai (1988). The phosphatase activity was measured by the method proposed by Tabatabai \& Bremner (1969). The arylsulfatase activity was determined by the method of Tabatabai \& Bremner (1970). The urease activity was determined according to the method proposed by Kandeler \& Gerber (1988). The $q \mathrm{CO}_{2}$ was calculated as the ratio of basal respiration to $\mathrm{MBC}$. The $q \mathrm{CO}_{2}$ results were expressed as $\mathrm{g} \mathrm{CO}_{2}-\mathrm{C} \mathrm{d}^{-1} \mathrm{~g}^{-1} \mathrm{MBC}$. The $\mathrm{qMic}$ was calculated as the ratio between $\mathrm{MBC}$ and TOC. The results are expressed on the basis of oven-dried soil. All measurements were performed in triplicate.

\subsection{Statistical analysis}

Split-split plot analysis of variance (ANOVA) was used to test the effect of different sites (Grassland, Cerrado SS and Cerradao), seasons (dry and rainy season) and the interaction between sites and seasons on the evaluated soil microbial properties.

We used non-metric multidimensional scaling (Kruskal, 1964) (NMS) to assess the effects of the different vegetation types on the soil microbial properties using the Sørensen distance measure and the 'slow and thorough' autopilot setting. Prior to analysis, the data were normalized by totals for each variable to account for the differences in the variable units. To interpret the relationship between microbial properties and chemical and microclimatic properties with the ordination, we overlaid the second matrix of microbial variables and chemical and microclimatic properties and calculated the linear correlations between the properties and ordination axes.

The statistical differences between areas and seasons were analyzed using the Multiple Response Permutation Procedure (MRPP) based on the Sørensen distance. The MRPP is a nonparametric method to test differences between groups in the multidimensional space. The MRPP and NMS were performed using the PC-ORD 6.0 statistical package (MJM Software, Gleneden Beach, OR, USA).

\section{RESULTS}

Site, sampling period and their interaction significantly influenced the soil microbial biomass and enzyme activities. The only exceptions were urease activity, which showed no significant difference between sites, and $\mathrm{qCO}_{2}$ which only showed significant difference between sampling times. In addition, the interaction (site $\times$ sampling time) did not influence the arylsulfatase or urease activities.

Soil conditions, i.e., chemical and microclimatic properties, varied across the Cerrado gradient (Table 2). Soil temperature did not vary during the rainy season 
but was highest in CG during the dry season. The $\mathrm{pH}$ values were highest in $\mathrm{CG}$, while the $\mathrm{Ca}+\mathrm{Mg}, \mathrm{K}, \mathrm{P}, \mathrm{N}$ and TOC values were highest in CSS and CD in both seasons.
Similarly, the soil microbial properties showed significant changes across the Cerrado gradient (Figure 1). The highest and lowest $\mathrm{MBC}$ and $\mathrm{MBN}$ values were found in $\mathrm{CD}$ and $\mathrm{CG}$, respectively, in

Table 2. Soil microclimatic and chemical properties at different sites across the cerrado gradient.

\begin{tabular}{|c|c|c|c|c|c|c|c|c|c|c|}
\hline \multirow{2}{*}{ Site } & Temp & Moist & \multirow{2}{*}{$\mathrm{pH}$} & $\mathbf{H}+\mathbf{A l}$ & $\mathrm{Ca}+\mathrm{Mg}$ & $\mathbf{K}$ & $\mathrm{CEC}$ & \multirow{2}{*}{$\frac{P}{\mathrm{mg} \mathrm{kg}^{-1}}$} & \multirow{2}{*}{ TOC } & \multirow{2}{*}{ TN } \\
\hline & ${ }^{\circ} \mathrm{C}$ & $\mathrm{g} \mathrm{g}^{-1}$ & & \multicolumn{4}{|c|}{ 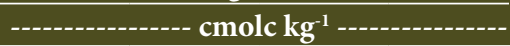 } & & & \\
\hline \multicolumn{11}{|c|}{ Rainy season } \\
\hline CG & $27.2^{\mathrm{a}}$ & $0.08^{c}$ & $4.95^{\mathrm{a}}$ & $1.52^{\mathrm{c}}$ & $0.14^{\mathrm{b}}$ & $1.33^{\mathrm{b}}$ & $1.68^{\mathrm{b}}$ & $3.57^{\mathrm{b}}$ & $4.46^{\mathrm{b}}$ & $0.23^{\mathrm{b}}$ \\
\hline CSS & $26.5^{\mathrm{a}}$ & $0.10^{\mathrm{b}}$ & $4.85^{\mathrm{b}}$ & $3.33^{\mathrm{b}}$ & $0.45^{\mathrm{a}}$ & $1.86^{\mathrm{a}}$ & $2.66^{\mathrm{a}}$ & $4.87^{\mathrm{a}}$ & $8.12^{\mathrm{a}}$ & $0.37^{\mathrm{a}}$ \\
\hline CD & $26.3^{\mathrm{a}}$ & $0.12^{\mathrm{a}}$ & $4.79^{\mathrm{b}}$ & $4.86^{\mathrm{a}}$ & $0.42^{\mathrm{a}}$ & $1.80^{\mathrm{a}}$ & $2.58^{\mathrm{a}}$ & $4.81^{\mathrm{a}}$ & $8.84^{\mathrm{a}}$ & $0.39^{\mathrm{a}}$ \\
\hline \multicolumn{11}{|c|}{ Dry season } \\
\hline CG & $39.7^{\mathrm{a}}$ & $0.001^{\mathrm{a}}$ & $4.81^{\mathrm{a}}$ & $1.35^{c}$ & $0.26^{\mathrm{b}}$ & $1.13^{\mathrm{b}}$ & $1.70^{\mathrm{b}}$ & $1.89^{\mathrm{b}}$ & $4.52^{b}$ & $0.20^{\mathrm{b}}$ \\
\hline CSS & $33.8^{\mathrm{b}}$ & $0.001^{\mathrm{a}}$ & $3.89^{\mathrm{b}}$ & $2.60^{\mathrm{b}}$ & $0.53^{\mathrm{a}}$ & $1.59^{\mathrm{a}}$ & $2.46^{\mathrm{a}}$ & $3.01^{\mathrm{a}}$ & $7.50^{\mathrm{a}}$ & $0.32^{\mathrm{a}}$ \\
\hline $\mathrm{CD}$ & $32.8^{\mathrm{b}}$ & $0.002^{\mathrm{a}}$ & $4.26^{\mathrm{b}}$ & $3.56^{\mathrm{a}}$ & $0.47^{\mathrm{a}}$ & $1.76^{\mathrm{a}}$ & $2.75^{\mathrm{a}}$ & $3.04^{\mathrm{a}}$ & $8.57^{\mathrm{a}}$ & $0.35^{\mathrm{a}}$ \\
\hline
\end{tabular}

Campo graminoide (CG); Cerrado strictu sensu (CSS); Cerradao (CD); Temp: soil temperature; Moist: soil moisture; CEC: cation exchange capacity; TOC: total organic C; TN: total N. In each column, means followed by the same letters do not differ significantly to the level of $5 \%$.
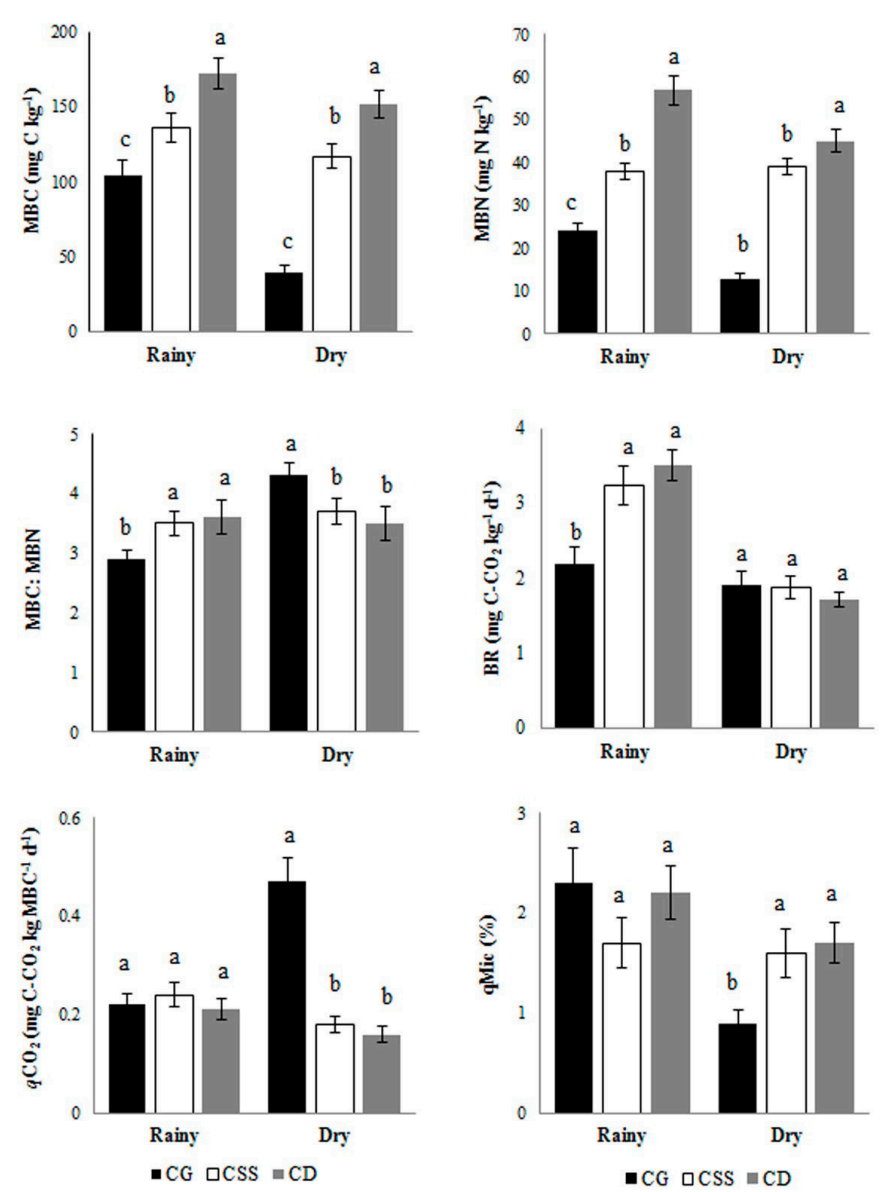

Figure 1. Soil microbial biomass $\mathrm{C}(\mathrm{MBC})$ and $\mathrm{N}(\mathrm{MBN}), \mathrm{MBC}: \mathrm{MBN}$ ratio, basal respiration (BR), metabolic $\left(\mathrm{qCO}_{2}\right)$, and microbial (qMic) quotients across the Cerrado gradient during the rainy and dry seasons. Campo graminoide (CG); Cerrado strictu sensu (CSS); Cerradao (CD). Bars indicate standard deviation. In each season, means followed by the same letters do not differ significantly to the level of $5 \%$. 
both seasons. The MBC:MBN ratio differed between sites in both seasons. In the rainy season, CSS and CD presented the highest values; while in the dry season, CG presented the highest values.

Soil respiration differed between sites during the rainy season, where CSS and CD presented the highest values, while in the dry season, the values were similar between sites. The microbial indices, i.e., $\mathrm{qCO}_{2}$ and qMic, did not vary between sites during the rainy season. In the dry season, these indices showed a different pattern, where $\mathrm{qCO}_{2}$ and qMic were, respectively, the highest and lowest in CG compared to the other sites.

The dehydrogenase, $\beta$-glycosidase and arylsulfatase activity and FDA hydrolysis showed lower values in CG than at the other sites, during both seasons (Figure 2). By contrast, the phosphatase and urease activity levels did not vary in the rainy season. During the dry season, phosphatase activity was highest in CG, while urease activity was highest in CG and CD.

The NMS explained $95 \%$ of the total variation distributed on axis $1(73 \%)$ and axis 2 (22\%) (Figure 3).

The distribution of samples along axis 1 showed a positive correlation with soil microbial properties, except for $\mathrm{qCO}_{2}$, which was negatively correlated (Table 3). Among the physicochemical variables, only $\mathrm{pH}$ showed no correlation with axis 1 . Axis 2 separated the sites by season and correlated positively the most with biological variables and the moisture percentage. Soil temperature was negatively correlated with the two axes of ordination.

The analysis of MRPP showed that the sites were clearly separated into different groups, indicating
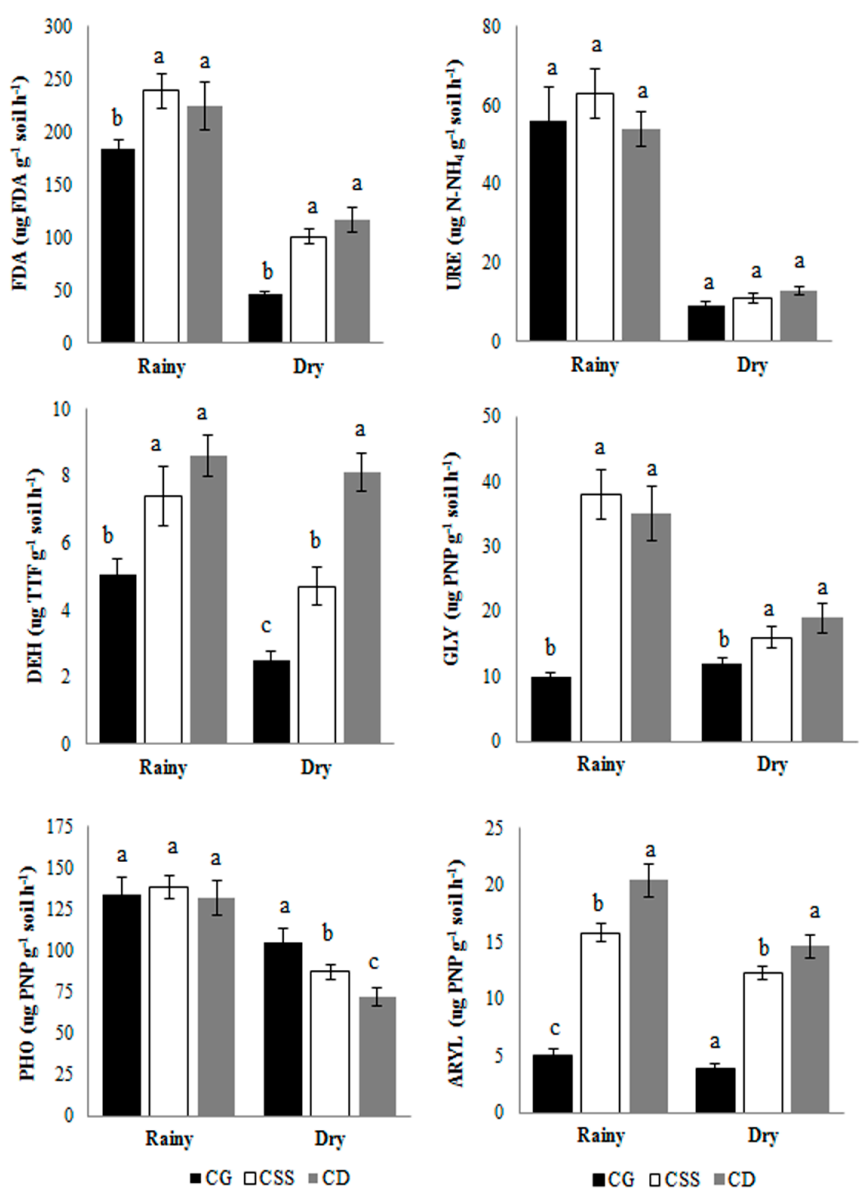

Figure 2. Activities of FDA (FDA), urease (URE), dehydrogenase (DEH), $\beta$-glucosidase (GLY), phosphatase (PHO), and arylsulfatase (ARYL) across the Cerrado gradient in the rainy and dry seasons. Campo graminoide (CG); Cerrado strictu sensu (CSS); Cerradao (CD). Bars indicate standard deviation. In each season, means followed by the same letters do not differ significantly to the level of $5 \%$. 
Table 3. Pearson's correlation coefficient ( $r$ ) between the soil properties and axes 1 and 2 of the NMS ordination.

\begin{tabular}{|c|c|c|}
\hline \multirow{2}{*}{ Variables } & \multicolumn{2}{|c|}{ Correlation coefficients } \\
\hline & Axis 1 & Axis 2 \\
\hline MBC & $0.93^{\star * *}$ & $0.55^{\star *}$ \\
\hline qMic & $0.51^{* * *}$ & $0.62^{* * *}$ \\
\hline BR & $0.45^{\star \star}$ & $0.71^{\star * *}$ \\
\hline $\mathrm{qCO}_{2}$ & $-0.76^{* * *}$ & $-0.26^{\mathrm{n} . \mathrm{s}}$ \\
\hline DEH & $0.81^{\star * *}$ & $0.59^{* *}$ \\
\hline FDA & $0.57^{\star * *}$ & $0.96^{* * *}$ \\
\hline GLY & $0.66^{* * *}$ & $0.64^{* * *}$ \\
\hline PHO & $0.04^{\text {n.s }}$ & $0.77^{\star * *}$ \\
\hline ARYL & $0.90^{\star * *}$ & $0.50^{* *}$ \\
\hline URE & $0.31^{*}$ & $0.95^{* * *}$ \\
\hline MBN & $0.93^{* * *}$ & $0.43^{*}$ \\
\hline MBC:MBN & $0.08^{\text {n.s }}$ & $0.48^{* *}$ \\
\hline pH & $-0.13^{\mathrm{n} . \mathrm{s}}$ & $0.20^{\text {n.s }}$ \\
\hline $\mathbf{H}+\mathbf{A l}$ & $0.84^{* * *}$ & $0.44^{*}$ \\
\hline $\mathrm{Ca}+\mathrm{Mg}$ & $0.64^{* * *}$ & $-0.06^{\mathrm{n} . \mathrm{s}}$ \\
\hline K & $0.82^{\star * *}$ & $0.46^{\star}$ \\
\hline $\mathbf{P}$ & $0.68^{\star * *}$ & $0.88^{* * *}$ \\
\hline TOC & $0.82^{* * *}$ & $0.26^{\mathrm{n} . \mathrm{s}}$ \\
\hline $\mathrm{TN}$ & $0.68^{\star * *}$ & $0.13^{\mathrm{n} . \mathrm{s}}$ \\
\hline CTC & $0.84^{\star * *}$ & $0.23^{\text {n.s }}$ \\
\hline Moisture & $0.39^{* *}$ & $0.94^{* * *}$ \\
\hline Tem & $-0.58^{* * *}$ & $-0.89^{* * *}$ \\
\hline
\end{tabular}

n.s. non-significant at $5 \% ;{ }^{*} p<0.05 ;{ }^{* *} p<0.01 ;{ }^{* *} p<0.001$.

Table 4. $p$-values for MRPP comparisons with the different Cerrado areas in two periods.

\begin{tabular}{|cc|}
\hline Comparison & p-value \\
\hline CG_D vs. CSS_D & $0.000022^{* * *}$ \\
\hline CG_D vs. CD_D & $0.000019^{* * *}$ \\
\hline CG_D vs. CG_R & $0.000021^{* * *}$ \\
\hline CG_D vs. CSS_R & $0.000019^{* * *}$ \\
\hline CG_D vs. CD_R & $0.000019^{* * *}$ \\
\hline CSS_D vs. CD_D & $0.000024^{* * *}$ \\
\hline CSS_D vs. CG_R & $0.000019^{* * *}$ \\
\hline CSS_D vs. CSS_R & $0.000018^{* * *}$ \\
\hline CSS_D vs. CD_R & $0.000018^{* * *}$ \\
\hline CD_D vs. CG_R & $0.000018^{* * *}$ \\
\hline CD_D vs. CSS_R & $0.000017^{* * *}$ \\
\hline CD_D vs. CD_R & $0.000019^{* * *}$ \\
\hline CG_R vs. CSS_R & $0.000019^{* * *}$ \\
\hline CG_R vs. CD_R & $0.000018^{* * *}$ \\
\hline CSS_R vs. CD_R & $0.003015^{*}$ \\
\hline
\end{tabular}

Campo graminoide (CG); Cerrado strictu sensu (CSS); Cerradao (CD); D: dry season; R: rainy season; ${ }^{*} p<0.05$; ${ }^{* * *} p<0.001$.

that the distinct physiognomies and environmental conditions influenced the soil microbial biomass and enzymes (Table 4). The groups were ordinated from left to right as $\mathrm{CG}<\mathrm{CSS}<\mathrm{CD}$. The result was confirmed

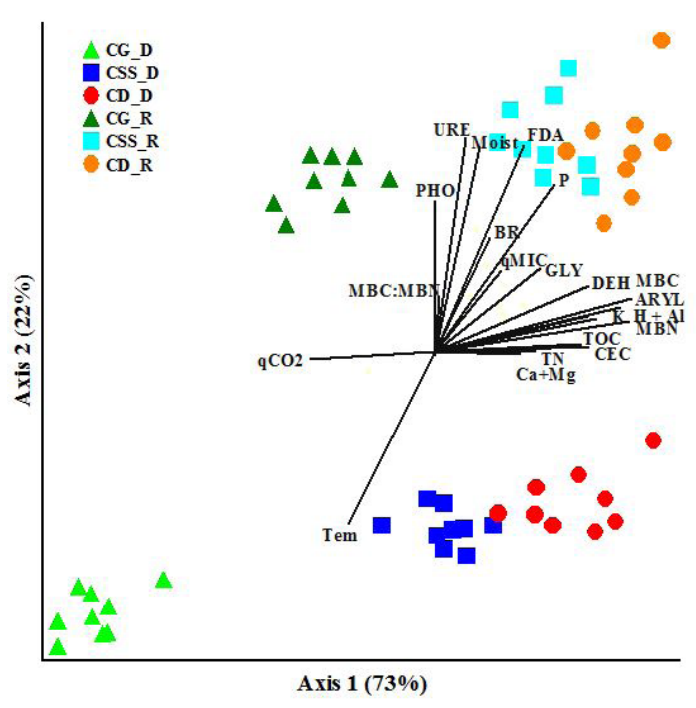

Figure 3. NMS ordination between soil conditions and microbial properties across the Cerrado gradient during the rainy and dry seasons. Campo graminoide (CG); Cerrado strictu sensu (CSS); Cerradao (CD); $\mathrm{R}$ : rainy season; D: dry season.

by Pearson's correlation, which showed an increase in soil microbial biomass and enzyme activity, while temperature decreased across the Cerrado gradient.

\section{DISCUSSION}

The study showed the consistent effect of different seasons on soil microbial variables, usually with lower values during the dry than in the rainy season. This result indicates that the seasons affect the soil microbial biomass status in Brazilian Cerrados (Mendes et al., 2012). Our study region presents two main seasons that differ by rainfall regime, and this characteristic alters soil moisture, which influences the soil microbial biomass and activity. According to Tabuchi et al. (2008), soil moisture significantly influences the soil microbial community by increasing the available organic matter from woody debris and thus stimulating soil microbial biomass (Eaton \& Chassot, 2012). Therefore, our results showed that the rainy season contributes to higher soil moisture and, consequently, increased soil microbial biomass and enzyme activities. Eaton \& Chassot (2012) studied forest soils from Monteverde Reserve in Costa Rica and found a strong relationship between soil moisture and soil microbial biomass. Our results are in agreement with Nardoto \& Bustamante (2003), 
who evaluated microbial variables in the Cerrado from Central Plateau, Brazil, and found higher soil microbial biomass and activity in the rainy season than during the dry season.

Different Brazilian Cerrado formations significantly influenced soil microbial variables due to the differences in the status of vegetation and soil properties found at these sites. Higher values for soil microbial biomass and activity were observed at CSS and CD and may be associated with the greater plant richness and diversity found at these sites, which provides a high quantity and quality of plant litter that contributes to the higher availability of above- and below-ground carbon sources for soil microbial biomass (Nsabimana et al., 2004). According to Ribeiro et al. (2011), the above-ground biomass in the Brazilian Cerrado varied from 12.8 to 107.3 ton ha ${ }^{-1}$, while the estimation of below-ground biomass ranged from 15.0 to 102.1 ton $\mathrm{ha}^{-1}$ in the grassland and Cerradao, respectively. Therefore, these differences in the litter contribution influenced the soil microbial biomass across the gradient. Additionally, some studies have reported that more diverse plant communities positively affect soil microorganisms (Berg \& Smalla, 2009; Wallenstein et al., 2007; Malchair et al., 2010; Lamb et al., 2011). Wallenstein et al. (2007) evaluated the bacterial community between Alaskan tussock and shrub tundra vegetation and found that plant communities regulate bacterial communities through the quantity and chemical quality of plant litter in the soil. Additionally, soil chemical properties positively influenced the soil microbial biomass in CSS and $\mathrm{CD}$ because nutrients, such as $\mathrm{P}$ and $\mathrm{K}$, contribute to increased microbial biomass (Araujo et al., 2012). Araujo et al. (2012) evaluated the bacterial community in a Cerrado gradient from southeastern Brazil, and found higher nutrient levels in the Cerradao. These properties influenced soil microorganisms through the input of diverse nutrient sources into the belowground system. In our study, we can highlight the finding of the highest TOC in CSS and CD compared with CG, which also influenced soil microbial biomass. According to Mendes et al. (2012), TOC was an important factor influencing soil microbial biomass and activity in the Cerrado SS and Cerradao. In a study in Cerrado from the Central Plateau, Mendes et al. (2012) observed that Cerradao had higher levels of organic $\mathrm{C}$ and soil microbial biomass than grassland.
Soil respiration showed different responses according to the rainy or dry season. In the dry season, the similar soil respiration values reflect the influence of soil environmental conditions, such as moisture and temperature, which drives microbial respiration. According to Bastida et al. (2008), soil respiration can provide information about seasonal effects on soil microorganisms. However, in the rainy season, the lowest basal respiration in CG suggests a limitation of $\mathrm{C}$ in the soil for soil microorganisms, which can be confirmed by the results from microbial indices, i.e., $\mathrm{qCO}_{2}$ and $\mathrm{qMic}$, which presented high and low values in CG, respectively. Thus, some limiting factors for microbial biomass, such as a low amount of organic residues (Gama-Rodrigues \& Gama-Rodrigues, 2008) and soil moisture (Mendes et al., 2012), may have contributed to the use of $\mathrm{C}$ by soil microorganisms for their maintenance, increasing $\mathrm{qCO}_{2}$. Therefore, on one hand, microbial biomass decreases, thereby reducing qMic, on the other, the highest qMic values found in CSS and CD reflect the microbial efficiency in converting organic $\mathrm{C}$ into microbial C (Leite et al., 2003; Fernandes et al., 2012).

The better soil conditions, i.e., organic C, nutrients, and moisture, found in CSS and CD positively influenced the enzyme activities in our study. Previously, Mendes et al. (2012) showed that in native or cropped Cerrado, these soil conditions influenced soil enzymes (Mendes et al., 2012). In particular, organic C exerts a significant effect on soil enzymes such as $\mathrm{C}, \mathrm{N}, \mathrm{P}$ and $\mathrm{S}$ for soil microorganisms (Emmerling et al., 2000), and thus, the enzyme activities increase according to the increase in organic matter content (Bending et al., 2002). In addition, soil moisture favors the highest substrate availability for soil enzymatic activity (Carvalho et al., 2010). Some previous studies have shown significant correlations between organic C content and FDA hydrolysis (Carneiro et al., 2013), dehydrogenase (Lino et al., 2016), $\beta$-glucosidase (Mganga et al., 2015) and arylsulfatase (Mendes et al., 2012).

The NMS analysis showed the separation of sites according to their environmental conditions, i.e., chemical and microclimate properties, and soil microbial properties. This separation was more significant in the dry season. Soils under a tropical dry season usually present lower soil microbial biomass and enzyme activity due to the limited availability of substrates, mainly influenced by low moisture (Allison \& Treseder, 
2008). Therefore, the soil under CG was more influenced by the seasons than other sites because of the lower plant cover and organic matter, which unfavorably reduces soil moisture and increases soil temperature. During the rainy season, the CSS and CD sites were closer, indicating similar and better soil conditions and nutrient availability, which contributed to the highest microbial biomass and activity.

\section{CONCLUSION}

The different physiognomies and soil conditions across the Cerrado gradient within the Sete Cidades National Park significantly influenced the status of soil microbial biomass and its biochemical processes. The soil microbial properties showed the variation under Campo Graminoide (CG) as a result of its soil conditions, i.e., temperature, moisture, and chemical properties, and less vegetation cover. On the other hand, soils under Cerradao (CD) presented high microbial biomass due to the better soil conditions and plant diversity.

\section{ACKNOWLEDGEMENTS}

The authors wish to thank "Fundação de Amparo à Pesquisa no Estado do Piaui" (FAPEPI) and "Conselho Nacional de Desenvolvimento Científico e Tecnológico" $(\mathrm{CNPq})$ for their financial support for this project through PRONEX (FAPEPI/CNPq 004/2012). A.S.F. Araujo is supported by grants from $\mathrm{CNPq}$ (Research's Productivity). V.M Santos is supported by grants from FAPEPI (Regional Scientific Development).

\section{SUBMISSION STATUS}

Received: 5 oct., 2017

Accepted: 6 oct., 2017

\section{CORRESPONDENCE TO}

\section{Ademir Sérgio de Araújo}

Departamento de Engenharia Agrícola e Solos, Universidade Federal do Piauí - UFPI, Rua Dirce de Oliveira, s/n, Campus da Socopo, CEP 64049-550, Teresina, PI, Brasil

e-mail: asfaruaj@yahoo.com.br

\section{FINANCIAL SUPPORT}

Fundação de Amparo à Pesquisa do Estado do Piauí (Grant / Award Number: “004/2012”).

\section{REFERENCES}

Alef K. Estimation of soil respiration. In: Alef K, Nannipieri P, editors. Methods in soil microbiology and biochemistry. New York: Academic Press; 1995.

Allison SD, Treseder KK. Warming and drying suppress microbial activity and carbon cycling in boreal forest soils. Gl Ch Biol 2008; 14(12): 2898-2909. http://dx.doi. org/10.1111/j.1365-2486.2008.01716.x.

Amaral AG, Pereira FFO, Munhoz CBR. Fitossociologia de uma área de cerrado rupestre na fazenda sucupira, Brasília - DF. Cerne 2006; 12: 350-359.

Araujo JF, Castro AP, Costa MMC, Togawa RC, Pappas GJ Jr, Quirino BF et al. Characterization of soil bacterial assemblies in brazilian savanna-like vegetation reveals acidobacteria dominance. Microbial Ecology 2012; 64(3): 760-770. http://dx.doi.org/10.1007/s00248-012-0057-3. PMid:22570118.

Bastida F, Barberá GG, García C, Hernández T. Influence of orientation, vegetation and season on soil microbial and biochemical characteristics under semiarid conditions. Applied Soil Ecology 2008; 38(1): 62-70. http://dx.doi. org/10.1016/j.apsoil.2007.09.002.

Bending GD, Turner MK, Jones JE. Interactions between crop residue and soil organic matter quality and the functional diversity of soil microbial communities. Soil Biology \& Biochemistry 2002; 34(8): 1073-1082. http:// dx.doi.org/10.1016/S0038-0717(02)00040-8.

Berg G, Smalla K. Plant species and soil type cooperatively shape the structure and function of microbial communities in the rhizosphere. FEMS Microbiology Ecology 2009; 68(1): 1-13. http://dx.doi.org/10.1111/j.1574-6941.2009.00654.x. PMid:19243436.

Bremner JM. Nitrogen total. In: Sparks DL, editor. Methods of soil analysis: part 3. Madison: America Society of Agronomy; 1996.

Burns RG, De Forest JL, Marxsen J, Sinsabaugh RL, Stromberger ME, Wallenstein MD et al. Soil enzymes in a changing environment: current knowledge and future directions. Soil Biology \& Biochemistry 2013; 58: 216-234. http://dx.doi.org/10.1016/j.soilbio.2012.11.009.

Carneiro MAC, Souza ED, Paulino HB, Sales LEO, Vilela LAV. Attributes quality indicators in cerrado soils surrounding the Parque Nacional das Emas, state of Goiás, Brazil. Bioscience Journal 2013; 29: 1857-1868.

Carvalho PCF, Anghinoni I, Moraes A, Souza ED, Sulc $\mathrm{RM}$, Lang CR et al. Managing grazing animals to achieve 
nutrient cycling and soil improvement in no-till integrated systems. Nutrient Cycling in Agroecosystems 2010; 88(2): 259-273. http://dx.doi.org/10.1007/s10705-010-9360-x.

Casida LE Jr, Klein DA, Santoro T. Soil dehydrogenase activity. Soil Science 1964; 98(6): 371-376. http://dx.doi. org/10.1097/00010694-196412000-00004.

Coutinho LM. O conceito de Cerrado. Revista Brasileira de Botânica 1978; 1: 17-23.

Eaton W, Chassot O. Characterization of soil ecosystems in Costa Rica using microbial community metrics. Tropical Ecology 2012; 53: 25-36.

Eivazi F, Tabatabai MA. Glucosidases and galactosidases in soils. Soil Biology \& Biochemistry 1988; 20(5): 601-606. http://dx.doi.org/10.1016/0038-0717(88)90141-1.

Emmerling C, Liebner C, Haubold-Rosar M, Katzur J, Schröder D. Impact of application of organic waste materials on microbial and enzyme activities of mine soils in the Lusatian coal mining region. Plant and Soil 2000; 220(1/2): 129-138. http://dx.doi.org/10.1023/A:1004784525209.

Empresa Brasileira de Pesquisa Agropecuária - EMBRAPA. Manual de análises químicas de solos, plantas e fertilizantes. Brasilia: Embrapa; 1999.

Fernandes MM, Carvalho MGC, Araujo JMR, Melo FR, Silva CA, Sampaio FMT et al. Matéria orgânica e biomassa microbiana em plantios de eucalipto no Cerrado piauiense. Floresta e Ambiente 2012; 19(4): 453-459. http://dx.doi. org/10.4322/floram.2012.061.

Gama-Rodrigues EF, Gama-Rodrigues AC. Biomassa microbiana e ciclagem de nutrientes. In: Santos GA, Silva LS, Canellas LP editors. Fundamentos da matéria orgânica do solo ecossistemas tropicais e subtropicais. Porto Alegre: Metrópole; 2008.

Kandeler E, Gerber H. Short-term assay of soil urease activity sing colorimetric determination of ammonium. Biology and Fertility of Soils 1988; 6(1): 68-72. http:// dx.doi.org/10.1007/BF00257924.

Kruskal JB. Multidimensional scaling by optimizing goodness-of-fit to a nonmetric hypothesis. Psychometrika 1964; 29(1): 1-28. http://dx.doi.org/10.1007/BF02289565.

Lamb EG, Kennedy N, Siciliano SD. Effects of plant species richness and evenness on soil microbial community diversity and function. Plant and Soil 2011; 338(1-2): 483-495. http://dx.doi.org/10.1007/s11104-010-0560-6.

Leite LFC, Mendonça ES, Machado PLOA, Matos ES. Total $\mathrm{C}$ and $\mathrm{N}$ storage and organic $\mathrm{C}$ pools of a Red Yellow Podzolic under conventional and no tillage at the Atlantic Forest Zone, Southeastern Brazil. Australian Journal of Soil Research 2003; 41(4): 717-730. http://dx.doi. org/10.1071/SR02037.

Lino IAN, Santos VM, Escobar IEC, Silva DCA, Araújo ASF, Maia LC. Soil enzymatic activity in Eucalyptus grandis plantations of different ages. Land Degradation \&
Development 2016; 27(1): 77-82. http://dx.doi.org/10.1002/ ldr.2454.

Lucena IC, Amorim RSS, Lobo FA, Baldoni RN, Matos DMS. Spatial heterogeneity of soils of the Cerrado-Pantanal ecotone. Revista Ciência Agronômica 2014; 45(4): 673-682. http://dx.doi.org/10.1590/S1806-66902014000400005.

Malchair S, De Boeck HJ, Lemmens CMHM, Merckx R, Nijs I, Ceulemans R et al. Do climate warming and plant species richness affect potential nitrification, basal respiration and ammonia-oxidizing bacteria in experimental grasslands? Soil Biology \& Biochemistry 2010; 42(11): 1944-1951. http://dx.doi.org/10.1016/j. soilbio.2010.07.006.

Marinari S, Mancinelli R, Campiglia E, Grego S. Chemical and biological indicators of soil quality in organic and conventional farming systems in Central Italy. Ecological Indicators 2006; 6(4): 701-711. http://dx.doi.org/10.1016/j. ecolind.2005.08.029.

Mendes IC, Fernandes MF, Chaer GM, Reis FB Jr. Biological functioning of Brazilian Cerrado soils under different vegetation types. Plant and Soil 2012; 359(1-2): 183-195. http://dx.doi.org/10.1007/s11104-012-1195-6.

Mganga KZ, Razavi BS, Kuzyakov Y. Microbial and enzymes response to nutrient additions in soils of Mt. Kilimanjaro region depending on land use. European Journal of Soil Biology 2015; 69: 33-40. http://dx.doi. org/10.1016/j.ejsobi.2015.05.001.

Nardoto GB, Bustamante MMC. Effects of fire on soil nitrogen dynamics and microbial biomass in savannas of Central Brazil. Pesquisa Agropecuária Brasileira 2003; 38(8): 955-962. http://dx.doi.org/10.1590/S0100204X2003000800008.

Nsabimana D, Haynes RJ, Wallis FM. Size, activity and catabolic diversity of the soil microbial biomass as affected by land use. Applied and Environmental Microbiology 2004; 26: 81-92.

Ribeiro J, Colli GR, Caldwell JP, Soares AMVM. An integrated trait-based framework to predict extinction risk and guide conservation planning in biodiversity hotspots. Biological Conservation 2016; 195: 214-223. http://dx.doi.org/10.1016/j.biocon.2015.12.042.

Ribeiro SC, Fehrmann L, Soares CPB, Jacovine LAG, Kleinn L, Gaspar RO. Above- and belowground biomass in a Brazilian Cerrado. Forest Ecology and Management 2011; 262(3): 491-499. http://dx.doi.org/10.1016/j. foreco.2011.04.017.

Schnürer J, Rosswall T. Fluorescein diacetate hydrolysis as a measure of total microbial activity in soil and litter. Applied and Environmental Microbiology 1982; 43(6): 1256-1261. PMid:16346026.

Tabatabai MA, Bremner JM. Use of p-nitrophenyl phosphate for assay of soil phosphatase activity. Soil 
Biology \& Biochemistry 1969; 1(4): 301-307. http://dx.doi. org/10.1016/0038-0717(69)90012-1.

Tabatabai MA, Bremner JM. Arylsulphatase activity in soils. Soil Science Society of America Journal 1970; 34(2): 225-229. http://dx.doi.org/10.2136/sssaj1970.03615995 003400020016x.

Tabuchi H, Kato K, Nioh I. Season and soil management affect soil microbial communities estimated using phospholipid fatty acid analysis in a continuous cabbage (Brassica oleracea var. capitata) cropping system. Soil Science and Plant Nutrition 2008; 54(3): 369-378. http:// dx.doi.org/10.1111/j.1747-0765.2008.00242.x.
Vance ED, Brookes PC, Jenkinson DS. An extraction method for measuring soil microbial biomass. Soil Biology \& Biochemistry 1987; 19(6): 703-707. http://dx.doi. org/10.1016/0038-0717(87)90052-6.

Wallenstein MD, McMahon S, Schimel J. Bacterial and fungal community structure in Arctic tundra tussock and shrub soils. FEMS Microbiology Ecology 2007; 59(2): 428435. http://dx.doi.org/10.1111/j.1574-6941.2006.00260.x. PMid:17313585.

Yeomans JC, Bremner JM. A rapid and precise method for routine determimation of organic carbon in soil. Soil Science and Plant Analysis 1998; 19: 1467-1476. 